\title{
Implications of COVID-19 in healthcare and medical education
}

\author{
Dixit SM' ID Ranjit $\mathrm{E}^{2}$, Dixit $\mathrm{H}^{3}$
}

'Sanjaya Mani Dixit, Assistant Professor; ${ }^{2}$ Eurek Ranjit, Lecturer; Department of Pharmacology; ${ }^{3}$ Hemang Dixit, Professor and Head, Medical Education Department; Kathmandu Medical College Teaching Hospital, Kathmandu, Nepal.

\begin{abstract}
COVID-19 is the game changer of the $21^{\text {st }}$ century. A novel coronavirus outbreak that emerged in late December 2019 in Wuhan, China has taken the world by storm and spread across the globe causing havoc ${ }^{1}$. It has brought about many changes in the way we live and react in all aspects of our lives. This applies very drastically to the way that both medical education and health services will have to be conducted and provided for a long time with the World Health Organization (WHO) stating that the novel coronavirus may never go away quite like the influenza virus².
\end{abstract}

Observing the latest data on the number of severe acute respiratory syndrome coronavirus 2 (SARS-CoV-2) infected patients, it is ironic that the USA, Brazil, Russia, India and UK have a maximum number of infected people by mid of June 2020. Both the US, which is at the forefront of healthcare system capable of developing new and innovative medications as well as therapies; and the National Health Service (NHS) of the UK which prided itself on countrywide coverage for seventy five years now are faced with some deficiencies due to COVID-19 pandemic. Russia the USSR too, had a polyclinic based health service in its many republics but its effectiveness decreased with difficult economic times. In

Access this article online

Website: www.jkmc.com.np

DOI: https://doi.org/10.3126/jkmc.v9i2.35520

HOW TO CITE

Dixit S M, Ranjit E, Dixit H. Implications of COVID-19 in healthcare and medical education. J Kathmandu Med Coll. 2020;9(2):63-5.

Address for correspondence

Mr. Sanjaya Mani Dixit

Assistant Professor, Department of Pharmacology

Kathmandu Medical College Teaching Hospital, Bhaktapur, Nepal

Email: sanjayadixit@gmail.com

Copyright $\odot 2020$ Journal of Kathmandu Medical College (JKMC)

ISSN: 2019-1785 (Print), 2091-1793 (Online)

(7) (8) This work is licensed under a Creative Commons Attribution-Non Commercial 4.0 International License.
Brazil it is probable that a large majority of the population might not have been covered by its health services. Surprisingly, two major cities of India - Mumbai and New Delhi are having COVID-19 peaks. These two cities boast of providing relatively better health services from wellknown institutions and are in the forefront of medical tourism. Many Nepali citizens flock there for treatment too. The increased number of coronavirus cases in these two cities may be because many out of town workers are living in densely populated areas in unsanitary conditions. On the other hand there are a few handful of countries which have managed to keep infections low or under control. Looking over the happenings and the consequences of the COVID-19 pandemic one sees various variables. Some countries e.g. South Korea, Taiwan, Japan and Germany had lower death rates. Was it because of the custom of wearing masks or of early lockdown? The models and the novel approaches they used to keep the infections and mortality rate low would have to be tried in other countries too. It is an accepted fact that people in South Asian countries are not averse to wearing masks and even frequent hand washing. Did these practices help? Despite more than 80 days of official lockdown in Nepal, the number of cases is increasing at an alarming rate due to ease of Lockdown and return of Nepali migrants from India and other countries via land and air many of whom had to live in unthinkable conditions at the country borders.

The world is still trying to figure out the various pathologic effects of the COVID-19 disease. The virus is known to cause hyperinflammatory response in the body, coupled with severe acute respiratory distress syndrome ${ }^{1}$. There are studies which implicate that various organ systems may be involved ${ }^{1,3}$. Deaths have occurred due to heart failure, renal failure, liver damage, shock and multiorgan failure'. It has been noted that there are multiple strains of coronavirus circulating around the world thereby showing the diversity of symptoms $\mathrm{s}^{4,5}$.

Some of the practices such as regular vaccinations with BCG and Polio were rumoured to be contributing to the lower rates of infection in developing countries where 
immunisation practices continued. It is hypothesized that BCG and polio vaccine might have helped induce trained immunity which could offer protection against COVID-196. However, all these hypotheses need to be scientifically proved. There are numerous ongoing trials with various potential medicines around the world. The medicines claimed to be beneficial further need to undergo rigorous trials to prove their efficacy. Conflicting reports on the efficacy of anti-malarial drugs for COVID-19 have surfaced, with the Lancet journal retracting the article which said the medicines might not be effective ${ }^{7,8}$. The WHO Solidarity trial has been going on in different parts of the world with various medicines ${ }^{9}$. There are reports of antiviral drugs such as Remdesivir, Lopinavir and Ritonavir plus also the steroid Dexamethasone being beneficial to patients suffering from COVID-199,10.

One result of this pandemic is the realisation of the need for health welfare services for the people and the novel models in order to prevent loss of lives and transmission as is occurring currently. Philosopher and historian Y. N. Harari feels that it should be the health care professionals who are the heroes of the future ${ }^{11}$. True the phrase 'Corona Warriors' is being uttered in many parts of the world. Latvia became the first nation to honour the healthcare professionals amidst the crisis by unveiling the statue of medics fighting COVID-19 but at the same time there are reports of violence against health professionals in other places ${ }^{12,13}$. What an irony! What a stark reality? What is going to be the situation in the future? Will such risks of violence and the high risk nature of work demotivate the future generations to pursue careers in healthcare sciences?

The urgent necessity in Nepal is that our health services be expanded so as to provide services to citizens all over our country.We need doctors, nurses, lab technicians, pharmacists and all other grades of health professionals as well as well-trained technicians and hospital support services staff. Institutes who produce Human Resources for Health (HRH) must be encouraged to produce more personnel, probably with support and encouragement from the Government, media, community as well as other

\section{REFERENCES}

1. Zaim S, Chong JH, Sankaranarayanan V, Harky A. COVID-19 and Multiorgan Response. Curr Probl Cardiol [Internet]. [cited 2020 Jun 19];45(8):[Epub ahead of print]. [PubMed | Full Text | DOI]

2. Coronavirus may never go away, World Health Organization warns - BBC News. BBC [Internet]. [cited 2020 Jun 18]. [Full Text] stakeholders. The present rule of restricting admissions for medical education to 100 students per year per institution must be changed forthwith to 150. After all, several leading colleges such as Kathmandu Medical College has already shown its capability by successfully teaching and training a batch of 150 medical students, who are now offering their services to patients both in Nepal and abroad. Similar action must be taken for other courses in the health field. Then there is the question of encouraging institutions in different parts of the country so that health services become more widespread and available.

Will there be candidates coming forward to be doctors, nurses and other health professionals with the current scenario of physical attacks and psychological insecurity? Will the likelihood of infections from such epidemics/ pandemics in future years deter young students coming in these fields? These issues must be tackled by Medical Educationists, Health care professionals and stakeholders in order to prevent collapse of the health care institutions and system as well.

The recent confusion in the Ministry of Health \& Population regarding RDTs, PCRs and ventilators suggests a need to improve our health systems. Much restructuring is required if the Health Rights of the Nepali people as mentioned in Constitution of Nepal is to be attained.

Our future is therefore dependent on the steps that we take, for the effect of this pandemic is going to continue for years to come. Our modes of living such as personal hygiene, social distancing and limiting gatherings would probably have to be maintained and practised for a number of years. Plans are required for setting up better healthcare services, medical education as well as all other education, restructuring of work-place, increased use of online technology, public transportation, especially air transportation? We need to plan at the earliest to decide on how we are going to educate the future generations not only the healthcare professionals but also other sectors including basic education itself since COVID-19 is here to stay with us for some years if not forever.

3. Latimer G, Corriveau C, DeBiasi RL, Jantausch B, Delaney M, Jacquot $\mathrm{C}$, et al. Cardiac dysfunction and thrombocytopenia-associated multiple organ failure inflammation phenotype in a severe paediatric case of COVID-19. Lancet Child Adolesc Heal. 2020 Jul 1;4(7):552-4. [PubMed | Full Text | DOI]

4. Hewings-Matin Y. COVID-19: How many strains of the new coronavirus are there? Medical News Today 
[Internet]. [cited 2020 Jun 19]. [Full Text]

5. Winston A. Coronavirus has mutated into at least 30 different strains study finds - The Jerusalem Post. The Jerusalem Post [Internet]. [cited 2020 Jun 19]. [Full Text]

6. O'Neill LAJ, Netea MG. BCG-induced trained immunity: can it offer protection against COVID-19? Vol. 20, Nature Reviews Immunology. Nature Research; 2020. p. 335-7. [PubMed | Full Text | DOI]

7. Mehra MR, Desai SS, Ruschitzka F, Patel AN. RETRACTED: Hydroxychloroquine or chloroquine with or without a macrolide for treatment of COVID-19: a multinational registry analysis. Lancet. 2020;0(0). [PubMed | Full Text | DOI]

8. Joseph A. Lancet, NEJM retract Covid-19 studies that sparked backlash. STAT [Internet]. 2020 [cited 2020 Jun 19]. [Full Text]
9. Solidarity clinical trial for COVID-19 treatments [Internet]. World Health Organization. 2020 [cited 2020 Jun 19]. [Full Text]

10. WHO welcomes preliminary results about dexamethasone use in treating critically ill COVID-19 patients [Internet]. WHO. 2020 [cited 2020 Jun 18]. [Full Text]

11. Yuval Noah Harari: "Will coronavirus change our attitudes to death? Quite the opposite" | Books | The Guardian [Internet]. [cited 2020 Jun 19]. [Full Text]

12. Latvian people first in the world to unveil a statue for doctors fighting Covid [Internet]. [cited 2020 Jun 19]. [Full Text]

13. Doctors 'manhandled' at Nepal Medical College myRepublica - The New York Times Partner, Latest news of Nepal in English, Latest News Articles [Internet]. [cited 2020 Jun 19]. [Full Text] 